\title{
Improved adherence to the ESPGHAN guidelines is necessary for diagnosing celiac disease in children: a single-center experience
}

\author{
Wing-Yu Siobhan LAU ${ }^{1,2}$, Paul Anthony HEATON ${ }^{1}$ and Siba Prosad PAUL ${ }^{1}$
}

Received: 26 July 2020 Accepted: 24 November 2020

\begin{abstract}
Background - Celiac disease (CD) is an immune-mediated systemic disorder elicited by the ingestion of gluten. The European Society for Paediatric Gastroenterology, Hepatology and Nutrition (ESPGHAN) guidelines published in 2012 suggested a no-biopsy pathway (NBP) for symptomatic children with IgA tissue transglutaminase (TGA-IgA) $\geq 10 x$ upper limit of normal (ULN). Biopsy confirmation remained mandatory for other cases. Objective -This retrospective case note study was aimed at evaluating the adherence to the ESPGHAN 2012 guidelines for diagnosing CD in our unit. Methods - Forty-three cases with positive TGA-IgA were identified by a laboratory database search from January 2013 to December 2019. 6 of 43 patients were not referred for a confirmation of CD diagnosis. Data was collected on the diagnostic pathways followed, and appropriateness of adherence was compared with the existing ESPGHAN guidelines. Results - A total of 37 cases were included with 35 children diagnosed with CD. 29/35 (83\%) were diagnosed via the NBP;15/29 (52\%) children did not meet all the criteria required for NBP, but were diagnosed and managed as having CD. 20/35 (57\%) children were diagnosed with CD in adherence to the 2012 guidelines. Conclusion - The recommended diagnostic guidelines were frequently not implemented; adherence to the guidelines may improve following regular educational sessions. The revised 2020 ESPGHAN guidelines which exclude HLA-DQ2/DQ8 testing would address the issue of diagnosis for the 10/15 NBP cases (with TGA-IgA >10xULN) in our study who did not have HLA testing and were therefore non-adherent to the 2012 diagnostic guidelines. NBP, with the reduced need for endoscopy may be beneficial in resource limited settings.
\end{abstract}

\section{INTRODUCTION}

Celiac disease (CD) is an immune-mediated systemic disorder, strongly dependent on the human leukocyte antigen (HLA)-DQ2/ DQ8 haplotypes. It is elicited by the ingestion of dietary gluten and related prolamines in genetically susceptible individuals. The prevalence of CD in children, as determined by serological screening in epidemiological studies from Europe and elsewhere, is around $1 \% 0^{(1,2)}$. Historically, upper gastrointestinal endoscopy (UGIE) with duodenal biopsy, usually following serological positivity, was the gold standard for diagnosing CD in children prior to the publication of the European Society for Paediatric Gastroenterology, Hepatology and Nutrition (ESPGHAN) guidelines in $2012^{(1)}$.

A no-biopsy pathway (NBP) was recommended by the ESPGHAN guidelines (2012) for symptomatic children provided that the triple criteria are fulfilled ${ }^{(1)}$ :

- TGA-IgA (immunoglobulin A based anti-tissue transglutaminase antibodies) is greater than or equal to ten times of the upper limit of normal (ULN) for the laboratory

- Second positive blood test utilising EMA-IgA (anti-endomysial antibodies)

- Positive HLA-DQ2/DQ8 haplotype
All other children with suspected CD who did not fulfil the NBP criteria would have still needed a biopsy based confirmation for diagnosing $\mathrm{CD}^{(1)}$.

The aim of this study was to evaluate the adherence to the ESPGHAN 2012 guidelines for diagnosing CD in our unit.

\section{METHODS}

This study was a single-center retrospective case note review of children with suspected CD. It was conducted in July 2020; cases with positive TGA-IgA were identified through the electronic database search between January 2013 and December 2019. All cases previously diagnosed with CD diagnosis but with positive TGA-IgA levels measured for monitoring purposes were excluded. Data was collected on presenting complaint, EMA-IgA level, HLA-DQ2/DQ8, age, sex, date of diagnosis and pathway [NBP or biopsy pathway] followed for making the diagnosis. All the data were collected and analysed on an Excel spreadsheet. This study was approved by the clinical governance team as a service review.

\section{RESULTS}

Forty-three cases with elevated TGA-IgA titers were identified. FIGURE 1 shows the diagnostic pathways followed for these 


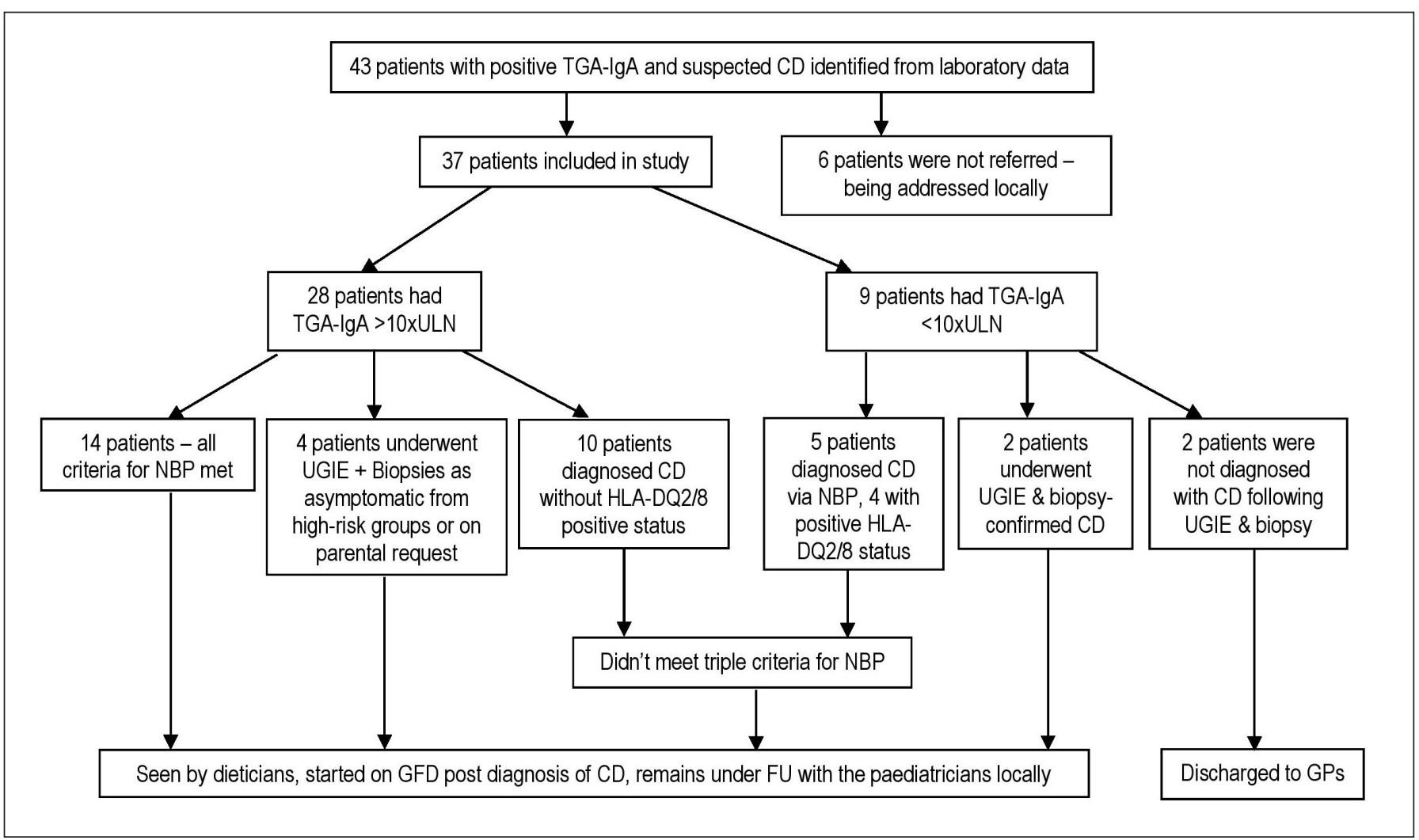

FIGURE 1. Flow chart showing diagnostic pathways followed for children with suspected celiac disease.

CD: celiac disease; FU: follow-up; GFD: gluten-free diet; GPs: general practitioners; HLA: human leucocyte antigen; IgA: immunoglobulin A; NBP: no-biopsy pathway; TGA: tissue transglutaminase antibodies; UGIE: upper gastrointestinal endoscopy; ULN: upper limit of normal.

children. Thirty-seven patients met the inclusion criteria, with 35 diagnosed with CD. There were 29/35 (83\%) cases diagnosed with CD by NBP in total, 14/29 (48\%) met all criteria for NBP, however, $15 / 29(52 \%)$ did not. Ten of the 24 symptomatic children with TGAIgA $>10 x U L N$ were diagnosed via NBP without a confirmation of their HLA-DQ2/DQ8 status. Five symptomatic children with TGA-IgA $<10 x U L N$ (ranging from 2 to 6 times the ULN) who were also EMA-IgA positive had a NBP diagnosis: of these four had a HLA-DQ2/DQ8 positive status. Six children (four with TGA-IgA $>10 x$ ULN) appropriately underwent UGIE and received a biopsy confirmation of CD.

Out of 35 children diagnosed with CD, 30 were symptomatic: 17 had gastrointestinal symptoms (diarrhoea, constipation, abdominal pain, vomiting, faltering growth), five had extra intestinal manifestation (iron deficiency anaemia, tiredness, pubertal delay), and seven had mixed features. Five patients who were asymptomatic at diagnosis of $\mathrm{CD}$ belonged to high risk groups: four had type 1 diabetes and one had CD in a first degree relative.

\section{DISCUSSION}

Our study showed full adherence to ESPGHAN 2012 guidelines in $22 / 37$ cases and $15 / 29(52 \%)$ only partially or did not meet the triple criteria for their diagnosis to be made by the NBP as per the ESPGHAN 2012 guidelines $^{(1)}$. HLA-DQ2/DQ8 positive status may have contributed to a NBP diagnosis of CD in $4 / 5$ cases where TGA-IgA was $<10 x U L N$.

\section{HLA testing does not improve accuracy of NBP}

Our study showed that 10/24 children with IgA-TGA > 10xULN were diagnosed via NBP without HLA confirmation. A multinational study (ProCeDE) involving 645 children with TGA-IgA $>10 x U L N$, all of whom subsequently had a biopsy confirmed $\mathrm{CD}$, suggested that HLA-DQ2/DQ8 testing did not contribute towards the diagnostic accuracy ${ }^{(3)}$. In a recent UK based study of 124 children diagnosed via NBP, HLA-DQ2/DQ8 testing was done in 101 patients $^{(4)}$. Out of 101, 100 were positive for HLADQ2/DQ8 haplotype, and the 1/101 who had a different HLA haplotype underwent biopsy and subsequently was confirmed to have $\mathrm{CD}^{(4)}$. The revised ESPGHAN guidelines published in 2020 have excluded the need for HLA-DQ2/DQ8 confirmation for a diagnosis of $\mathrm{CD}$ via NBP.

\section{Reduction of the need for pediatric endoscopies}

Our study documented that 28/37 cases in our center would have qualified for NBP according to the ESPGHAN 2020 guidelines and would have reduced the number of endoscopies by $76 \%$. A study from the Netherlands reported that the implementation of the 2012 ESPGHAN guidelines resulted in 54\% reduction in endoscopy ${ }^{(5)}$. Another UK based study showed 50\% reduction of endoscopies following the implementation of the ESPGHAN 2012 guidelines ${ }^{(4)}$. The estimated cost for biopsy-based diagnosis as available from a tertiary pediatric gastroenterology center based in Bristol in 2017 was $£ 1300^{(6)}$ whereas serology based NBP diagnosis costed $£ 65^{(6)}$. 


\section{Variation of how the diagnosis is made}

A limitation of our study was that five cases with TGA-IgA $<10 x U L N$ may have been inappropriately diagnosed with $C D$ via the NBP. Two of these five children had already been started on a gluten-free diet (GFD) by parent/dietician; there had been discussion with parents regarding gluten challenge and biopsy confirmation but parents did not wish for the child to resume dietary gluten as they perceived there had been significant clinical improvement with gluten exclusion. Review of the case notes for other three children identified a documented discussion being held with the pediatric gastroenterology team based in the tertiary gastroenterology center who had approved the NBP. Normalization of TGAIgA titers had occurred in all five patients when monitoring blood tests were reviewed. A recently published single center study from the UK highlighted that $3 / 75$ children with TGA-IgA $<10 x U L N$ were diagnosed via a NBP and parents had remained reluctant for a gluten re-challenge and subsequent biopsy confirmation ${ }^{(7)}$.

\section{Non-referral for confirmation of diagnosis of CD}

In our study, 6/43 (14\%) of children with positive TGA-IgA were not referred to a pediatrician for confirmation of $\mathrm{CD}$. This has been addressed locally, and these potentially missed cases are now being reassessed within the pediatric services. A study from the UK showed that 17/106 $(16 \%)$ were not referred for a confirmation of the diagnosis of $\mathrm{CD}$ following a positive TGA-IgA titer values ${ }^{(7)}$. In a population based Israeli study of 6417 children, although serology test was common, $44 \%$ of children with a positive serology test never received an endoscopy for confirmation of CD diagnosis ${ }^{(8)}$.

\section{The way forward}

ESPGHAN have updated their guidelines for CD in 2020 and it simplified the diagnostic pathways ${ }^{(2)}$. A firm diagnosis of NBP can now be established for symptomatic, and asymptomatic children from high risk groups (type 1 diabetes, first degree relatives of $C D$ patients, autoimmune hypothyroidism, Down syndrome, Turner syndrome), provided they fulfilled the criteria ${ }^{(2)}$ :

1. TGA-IgA $\geq 10 x U L N$

2. Positive EMA-IgA in a second serum sample

For all other children with suspected CD, the biopsy pathway still remain mandatory when TGA-IgA is $<10 x \mathrm{XLN}$, and in symptomatic children in low risk groups with TGA-IgA $\geq 10 x U L N$ detected coincidentally while screening for other asymptomatic opportunistic cases ${ }^{(2)}$.

The ESPGHAN 2012 guidelines were introduced in the Southwest England (SWE) in 2013 ${ }^{(9)}$. A survey of 100 consultant pediatricians in the SWE conducted in 2016-17 showed that only one-third of the respondents could state the triple criteria necessary for diagnosing $\mathrm{CD}$ via NBP in accordance to the ESPGHAN 2012 guidelines $^{(8)}$. Regular education updates for pediatricians and general practitioners may improve proper understanding and implementation of the 2020 guidelines as CD remains a lifelong diagnosis with commitment for GFD and monitoring blood tests ${ }^{(4,9)}$.

\section{Introduction of the NBP in resource limited settings}

The implementation of NBP for diagnosing CD could be beneficial for children in resource limited settings. A major challenge towards a confirmatory diagnosis of $\mathrm{CD}$ in resource-limited settings is likely to be the limited availability of standardized TGA-IgA assays, pediatric endoscopic facilities and anesthetists trained to administer general anesthesia safely to children ${ }^{(10)}$. Previous studies from resource limited settings have documented that the NBP could be implemented provided a pre-implementation evaluation of the local TGA-IgA titers of $>10 x$ ULN correlates with a subsequent histological confirmation of $\mathrm{CD}^{(11,12)}$. An Indian study of 142 children proved that there is a good correlation between children with high TGA-IgA titers and $\mathrm{CD}^{(11)}$. Similar results were shown in another study from Iraq where 70/72 children with TGA-IgA $>10 x \mathrm{ULN}$ received histological confirmation of $\mathrm{CD}^{(12)}$.

\section{The impact of the COVID-19 pandemic}

Recently published COVID-19 guidelines for pediatric gastroenterologists suggest that patients should be advised to continue a gluten containing diet until the services for endoscopy resumes and a biopsy-based diagnosis for relevant cases can be made ${ }^{(13)}$. In a recently conducted international survey of 145 institutions during the COVID-19 pandemic on changes in pediatric endoscopy policy, $67 \%$ centers responded that they would start treatment with GFD on children with suspected CD and positive TGA-IgA without undergoing endoscopy ${ }^{(14)}$. It was further highlighted that the NBP was more likely to be followed in institutions located in regions with $\geq 10,000$ COVID-19 cases $(P=0.0327)^{(14)}$.

\section{When the guidelines cannot be followed}

Though the majority of children with $\mathrm{CD}$ should be diagnosed using the ESPGHAN guidelines ${ }^{(2)}$, it should be acknowledged that challenging presentations will still occur when diagnosis and management have to individually tailored pragmatically in accordance with parental wishes. For example, when a child has suspected CD symptoms and at parental initiative a GFD had been started prior to any serological testing (often when CD has been suspected or proven in another family member); if the child has shown clinical improvement the family may be reluctant to reintroduce gluten into the diet purely for the purpose of confirming the diagnosis.

\section{CONCLUSION}

$\mathrm{CD}$ is a lifelong diagnosis which should be made with strict adherence to the ESPGHAN guidelines. While 15/29 (52\%) children did not meet the triple criteria for the NBP as recommended by the ESPGHAN (2012) guidelines, in 10 out of those 15 patients with TGA-IgA $>10 x$ ULN, the non-adherence was due to the HLA-DQ2/8 test being not done. The revised ESPGHAN guidelines (2020) will resolve the confusion highlighted by our study where in these cases as need for HLA-DQ2/DQ8 testing has been removed from the criteria for NBP diagnosis. However, in the other $5 / 15$ cases where TGA-IgA was $<10 \times$ ULN, nonadherence would still remain an issue. Regular educational sessions conducted locally and regionally may enhance the adherence to the diagnostic pathway as recommended by the ESPGHAN. The simplified diagnostic pathway published by the ESPGHAN in 2020 is likely to result in better and faster diagnosis of CD - something which would be particularly relevant during the COVID-19 pandemic and thereafter, and of potential application in resource limited settings.

\section{ACKNOWLEDGEMENT}

The authors would like to acknowledge the help from Dr 
David James, Consultant Chemical Pathologist, Department of Chemical Pathology and Mr Derek Truman, Quality Manager, General Pathology, both based at the Taunton and Somerset NHS Foundation Trust for their support with this project.

\section{Authors' contribution}

Paul SP and Heaton PA: project concept, supervision, prepared and edited the manuscript with comments and review from all authors. Paul SP and Lau WS: generation of patient list through database search, collected and analysed data. All authors have approved the uploaded draft.

\section{Orcid}

Wing-Yu Siobhan Lau: 0000-0002-3532-4799.

Paul Anthony Heaton: 0000-0002-7948-1737.

Siba Prosad Paul: 0000-0003-1267-1269.

Lau WS, Heaton PA, Paul SP. Uma melhor adesão às diretrizes da ESPGHAN é necessária para o diagnóstico da doença celíaca em crianças: uma experiência de um único centro. Arq Gastroenterol. 2021;58(2):164-7.

RESUMO - Contexto - A doença celíaca (DC) é uma doença sistêmica imuno-mediada provocada pela ingestão de glúten. As diretrizes da Sociedade Europeia de Gastroenterologia Pediátrica, Hepatologia e Nutrição (ESPGHAN) publicadas em 2012 sugeriram uma via sem biópsia (VSB) para crianças sintomáticas com transglutaminase de tecido IgA (TGA-IgA) $\geq 10 x$ limite superior do normal (LSN). A confirmação da biópsia permaneceu obrigatória para outros casos. Objetivo - Este estudo retrospectivo de dados de caso teve como objetivo avaliar a adesão às diretrizes da ESPGHAN 2012 para o diagnóstico de DC em nossa unidade. Métodos - Quarenta e três casos com TGA-IgA positivo foram identificados por uma pesquisa laboratorial de banco de dados de janeiro de 2013 a dezembro de 2019. Seis de 43 pacientes não foram encaminhados para confirmação do diagnóstico de DC. Os dados foram coletados nas vias diagnósticas seguidas, e a adequação da adesão foi comparada com as diretrizes ESPGHAN existentes. Resultados - Foram incluídos 37 casos com 35 crianças diagnosticadas com DC. Foram diagnosticados 29 (83\%) de 35 VSB; 15 (52\%) de 29 crianças não atenderam a todos os critérios exigidos para a VSB, mas foram diagnosticadas e gerenciadas como tendo DC. Vinte ( $57 \%$ ) em 35 foram diagnosticadas com DC em adesão às diretrizes de 2012. Conclusão - As diretrizes diagnósticas recomendadas não foram frequentemente implementadas; a adesão às diretrizes pode melhorar após sessões educativas regulares. As diretrizes revisadas ESPGHAN de 2020 que excluem os testes HLA-DQ2/ DQ8 abordariam a questão do diagnóstico para $10 \mathrm{em} 15$ casos VSB (com TGA-IgA >10x LSN) em nosso estudo os quais não fizeram testes de HLA e, portanto, não aderiram às diretrizes de diagnóstico de 2012. A VSB, com a necessidade reduzida de endoscopia, pode ser benéfica em configurações limitadas de recursos.

\section{REFERENCES}

1. Husby S, Koletzko S, Korponay-Szabó IR, Mearin ML, Phillips A, Shamir R, et al. European Society for Pediatric Gastroenterology, Hepatology, and Nutrition guidelines for the diagnosis of coeliac disease. J Pediatr Gastroenterol Nutr. 2012;54:136-60. doi: 10.1097/MPG.0b013e31821a23d0.

2. Husby S, Koletzko S, Korponay-Szabó I, Kurppa K, Mearin ML, Ribes-Koninckx $\mathrm{C}$, et al. European Society Paediatric Gastroenterology, Hepatology and Nutrition Guidelines for Diagnosing Coeliac Disease 2020. J Pediatr Gastroenterol Nutr. 2020;70:141-56. doi: 10.1097/MPG.0000000000002497.

3. Werkstetter K, Korponay-Szabó I, Popp A, Villanacci V, Salemme M, Heilig G, et al. Accuracy in Diagnosis of Celiac Disease Without Biopsies in Clinical Practice. Gastroenterology. 2017;153:924-35. doi: 10.1053/j.gastro.2017.06.002.

4. Paul SP, Chopra J, Vaina CL, Mallikarjuna A, Basude D. HLA-DQ2/DQ8 typing for non-biopsy diagnosis of coeliac disease: is it necessary? Arch Dis Child 2019;104:1119-20. doi: 10.1136/archdischild-2019-317297.

5. Landman M, Theuns S, van Wering H, Tramper G, van Ledden M, Rietveld E, et al. Evaluation of the implementation of the 2012 ESPGHAN guideline of Coeliac disease in children: results of a retrospective study in the Netherlands. Arch Dis Child. 2020;105:413. doi: 10.1136/archdischild-2018-316490.

6. Paul SP, Harries SL, Basude D. Barriers to implementing the revised ESPGHAN guidelines for coeliac disease in children: a cross-sectional survey of coeliac screen reporting in laboratories in England. Arch Dis Child. 2017;102:942-6. doi: 10.1136/archdischild-2016-312027.

7. Paul SP, Chan YJ, Bailey JR. Diagnosing childhood celiac disease using ES PGHAN 2012 and 2020 guidelines: Tighter adherence is required! Indian J Gastroenterol. 2020;39:621-23. doi: 10.1007/s12664-020-01062-7.
8. Guz-Mark A, Feldman B, Ghilai A, Hoshen M, Cohen H, Shkalim Zemer V, et al. High rates of serology testing for coeliac disease, and low rates of endoscopy in serologically positive children and adults in Israel. Eur J of Gastroenterol Hepatol. 2020;32:329-34. doi: 10.1097/MEG.0000000000001613.

9. Paul SP, Adams HL, Basude D, Collaborators. Interpretation and implementation of the revised European Society for Paediatric Gastroenterology Hepatology and Nutrition (ESPGHAN) guidelines on pediatric celiac disease amongst consultant general pediatricians in Southwest of England. Indian J Gastroenterol. 2019:38;203-10. doi: 10.1007/s12664-019-00952-9.

10. Paul SP, Stanton LK, Adams HL, Basude D. Coeliac disease in children: the need to improve awareness in resource-limited settings. Sudan J Paediatr. 2019; 19:6-13. doi: 10.24911/SJP.106-1549488256.

11. Bhattacharya M, Lomash A, Sakhuja P, Dubey A, Kapoor S. Clinical and histopathological correlation of duodenal biopsy with IgA anti-tissue transglutaminase titers in children with celiac disease. Indian J Gastroenterol. 2014;33:350-4. doi: 10.1007/s12664-014-0464-0

12. Al-Musawi ZM. Is high tissue transglutaminase antibody titers enough to diagnose coeliac disease in children? Karbala J Med. 2010;3:860-6.

13. Murray KF, Gold BD, Shamir R, Agostoni C, Pierre-Alvarez R, Kolacek S, et al. Coronavirus Disease 2019 and the Pediatric Gastroenterologist. J Pediatr Gastroenterol Nutr. 2020;70:720-6. doi: 10.1097/MPG.0000000000002730.

14. Ruan W, Fishman DS, Lerner DG, Engevik MA, Elmunzer BJ, Walsh CM, et al. Changes in Pediatric Endoscopic Practice during the COVID-19 Pandemic: Results from an International Survey. Gastroenterology. 2020;159:1547-50. doi: 10.1053/j.gastro.2020.05.068. 